\title{
The Limitations ACt and OIL and Gas Transactions
}

\section{AlLAN D. NIELSEN ${ }^{*}$ AND DARWIN A. SCHOFER ${ }^{\bullet}$}

This article was written in 1998 while the Limitation of Actions Act was still in force. On March 1, 1999, the Limitations Act was proclaimed which had the effect of repealing the Limitation of Actions Act

The article examines the Limitation of Actions Act with respect 10 the common law principle of discoverability, and the length and commencement dates of the limitations periods of oil and gas actions in Alberta. It then compares these provisions to the scope of the new Limitations Act, with particular attention paid to the legislated discoverability rule. With respect to the courts' analysis of limitations issues, the authors survey pertinent case law, illustrating the complexity of the limitations scheme under the old Limitation of Actions Act
Le présent article a été rédigé en 1998, alors que la Limitation of Actions Act était en vigueur. Le I" mars 1999. la Limitations Act a été adoptée, abrogeant la Limitation of Actions Act

$L$ 'article étudie la présente loi sur les prescriptions concernant le principe d'acces de la common law. et la durée et les dates d'entrée en vigueur des délais de prescription des actions dans le secteur pétrolier et gazier en Alberta. Il compare ensuite ces dispositions à la portée de la nouvelle loi et s'attache en particulier à la règle de la possibilité de découvrir le préjudice subi. En ce qui touche l'analyse des questions de prescriptions par les tribunaux, les auteurs examinent le droil jurisprudentiel, illustrant ainsi la complexité du sujet aux termes de l'ancienne Limitation of Actions Act

\section{TABLE OF CONTENTS}

I. INTRODUCTION .................... 286

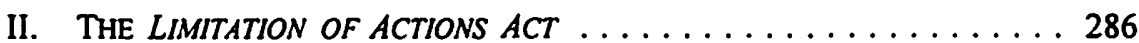

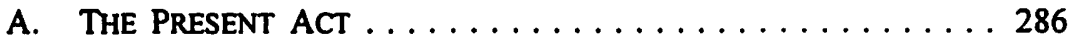

B. THE DisCOVERABILITY PRINCIPLE IN ALbERTA

CONTRACT AND TORT LAW ............. 288

C. LIMITATION PERIOD FOR AN ACTION TO RECOVER LAND . . . 290

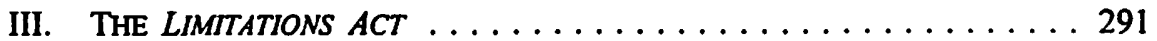

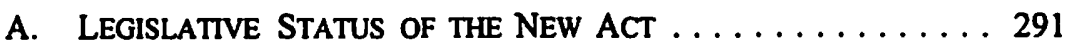

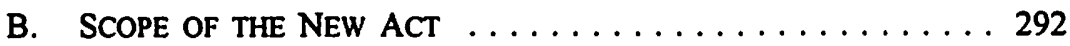

C. LimitATION PERIODS AND THE DISCOVERABILITY

PRINCIPLE UNDER THE NEW ACT . . . . . . . . . . . . . 293

D. TRANSition PERIOd for the New ACt . . . . . . . . . 294

E. EXCEPTIONS TO THE Limitations PERIODS

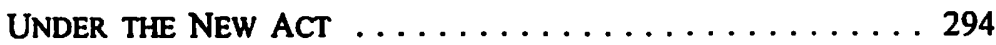

IV. OIL AND GAS TRANSACTIONS AND

Limitation Considerations . . . . . . . . . . . . . . 295

A. LIMTATION CONSIDERATIONS UNDER THE

PRESENT ACt AND THE NEW ACT . . . . . . . . . . . 295

B. OIL AND GAS CASES DECIDED UNDER

THE PRESENT ACt . . . . . . . . . . . . . . . . 296

C. THE EFFECT OF THE NEW ACT ON OIL AND

Gas Transactions . . . . . . . . . . . . . . . . 299

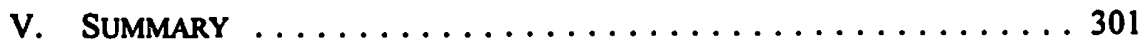

- Partner, Howard, Mackie, Calgary, Alberta.

-. Associate, Howard, Mackie, Calgary, Alberta. 


\section{INTRODUCTION}

The law of limitations in Alberta is currently convoluted and complex. Different types of actions have limitation periods with different lengths and different commencement dates, even in the circumstance where more than one type of action arises from a single individual event. As a result, the Alberta legislature has seen fit to enact, but not yet proclaim, a new limitations statute that will radically change some types of analysis endemic in the practice of limitations law in Alberta today.

This article examines some of the features associated with the core limitations statute presently in force in Alberta, including a brief overview of the history of the statute, the applicability of the common law principle of "discoverability" to the present limitations regime, and the length and commencement dates of the limitation periods associated with the actions most frequently encountered in Alberta's oil and gas industry.

The new limitations statute is then examined and the salient features of the statute, including the scope of the act, the incorporation of a discoverability rule into the act, and the limitation periods and exceptions thereto set forth in the act, are all briefly analyzed. The analysis assists in understanding the scheme behind the new act and provides the framework for the comparison of the substantive aspects of the new act with the limitations scheme currently in place.

Case law pertinent to the oil and gas industry is then reviewed to illustrate the types of analysis currently required from the courts to effectively adjudicate upon disputes involving limitation issues and to highlight the types of actions that involve limitation considerations arising from transactions commonly encountered in the oil and gas industry. The review is helpful in identifying how the new statute should significantly streamline some of the analyses and processes currently required under the present limitations act.

Finally, certain practical considerations relevant to oil and gas companies operating under the new limitations statute will be brought to the attention of the reader.

\section{THE LIMITATION OF ACTIONS ACT}

\section{A. The Present Act}

The law of limitations is wholly a creature of statute. Limitation periods were unknown to the common law, although equity developed the doctrine of laches. Alberta limitations law is based on the traditional English statutory approach. Statutory measures that limit the period within which an action must be commenced or else be 
barred have a history dating back to a statute enacted in England in 1623, ' namely, the Limitation Act, 1623 (U.K.). ${ }^{2}$

The central statute in the current Alberta limitations system is the Limitation of Actions Act $^{3}$ originally enacted in 1935 . $^{4}$ The most significant amendments to the present Act were made in $1966^{5}$ and eliminated certain short limitation periods and consolidated a number of limitation provisions, formerly found in other statutes, into the present Act. $^{6}$ Although the present Act is a significant improvement over the limitations system embodied in its English predecessors, it is still based on a strategy formulated over three and a half centuries ago.' Although the present Act is the core of Alberta limitations law, it is not comprehensive and other specific limitation periods and notice periods are contained in a multiplicity of Alberta statutes.

The purpose of the statutory limitation scheme is to set forth a time period in which a particular action must be commenced. If the action is commenced after the expiration of such time period, the defendant may successfully defend the action by expressly pleading the applicable limitation period as a defence to the action. If the court holds that the plaintiff did in fact commence the action after the expiration of the applicable limitation period, the action will not be available to the plaintiff. It is important to note that the courts do not automatically consider the limitation periods that may be applicable to a particular action. Rather, a limitation period will be considered by the court only if the defendant to the action expressly pleads the limitation period as a defence.

The present Act contains three main limitation periods typically applicable to oil and gas related matters. Under the present Act, actions based on certain torts, including trespass or injury to real property or chattels and the conversion of chattels, must be commenced within two years after the cause of action arose. ${ }^{8}$ Actions based on breach of contract must be commenced within six years after the cause of action arose, ${ }^{9}$ and actions based on proceedings to recover land must be commenced within ten years after the right to do so first accrued to the claimant. ${ }^{10}$ Also, part 7 of the present Act provides that there is no limitation period applicable to an action by a beneficiary against a trustee for a breach of trust. Notwithstanding that at first glance the application of these limitation periods may seem relatively straightforward, the law associated with limitation periods is replete with complex issues and divergent case law.

Alberta Law Reform Institute, Limitations, Report No. 55 (Edmonton: Alberta Law Reform Institute, 1989).

21 Jac.1, c. 16.

R.S.A. 1980, c. L-15 [hereinafter the "present Act"].

Limitation of Actions Act, S.A. 1935, c. 8.

An Act to Amend the Law Respecting Limitation of Actions in Tort, S.A. 1966, c. 49.

Supra note 1 at 15.

Ibid.

Supra note 3, s. 51.

Ibid., s. 4.

Ibid., s. 18. 
A key issue in limitations law turns on the determination of the date on which a particular limitation period commences and the principle of "discoverability."

\section{B. The Discoverability Principle in alberta Contract and Tort law}

Throughout the 1970s and into the 1980s, Canadian courts struggled with the issue regarding when a cause of action accrues in the tort of negligence for the purpose of the commencement of a limitation period." One of the then leading English cases available for Canadian courts to consider was Pirelli General Cable Works Ltd. v. Oscar Faber \& Partners. ${ }^{12}$ In Pirelli, the House of Lords held that a cause of action in the tort of negligence arose upon damage being sustained whether the damage was discoverable at that time or not, and that the common law contained no "discoverability" principle whereby the commencement of a limitation period would be delayed until the plaintiff discovered the damage or ought to have, with reasonable diligence, discovered the material facts which gave rise to his claim. ${ }^{13}$

Shortly after Pirelli was decided, the Supreme Court of Canada had the opportunity to consider the discoverability issue in the 1984 decision of Kamloops v. Nielsen. ${ }^{14}$ In Kamloops, the Supreme Court of Canada rejected the position set forth by the House of Lords in Pirelli, and adopted a discoverability principle whereby a cause of action in the tort of negligence would not accrue until the plaintiff had, or ought to have, discovered the damage which he had sustained. ${ }^{15}$ Notwithstanding that one might expect Kamloops to provide guidance in determining the commencement date of a cause of action founded on the tort of negligence, the position adopted by the Alberta Court of Appeal in the case of Costigan v. Ruzicka, ${ }^{16}$ which was decided almost contemporaneously with, but without knowledge of Kamloops, left the issue of discoverability far from being free of doubt. In Costigan, a unanimous Alberta Court of Appeal followed Pirelli, and held that the tort action before the court was statutebarred before the plaintiff had reason to know that he had a cause of action against a negligent solicitor.

N. Rafferty, "Limitation Periods in Negligence and the Hidden Cause of Action" (1986) 12 Can. Bus. L.J. 338.

[1983] 1 All E.R. 65 (H.L.) [hereinafter Pirelli].

N. Rafferty, Case Comment on McWhorter v. Alberla (Registrar, North Alberta Land Registration District) (1988) 57 Alta. L.R. (2d) 335.

[1984] 2 S.C.R. 2 [hereinafter Kamloops].

Wilson J. wrote the judgment for the three to two majority in Kamloops and, at 40, stated:

But perhaps the most serious concem is the injustice of a law which statute-bars a claim before the plaintiff is even aware of its existence.... This Court is in the happy position of being free to adopt or reject Pirelli. I would reject it.... As Lord Fraser pointed out in Pirelli the postponement of the accrual of the cause of action until the date of discoverability may involve the courts in the investigation of facts many years after their occurrence.... It seems to me, however, to be much the lesser of two evils.

[1984] 6 W.W.R. I (Alta. C.A.); leave to appeal refused (1984), 33 Alta. L.R. (2d) xxxvi (S.C.C.) [hereinafter Costigan]. 
The Supreme Court of Canada again considered the discoverability principle in the 1986 decision of Central Trust Company v. Rafuse, in which Le Dain J. delivered the judgment of the Court and wrote:

I am thus of the view that the judgment of the majority in Kamloops laid down a general rule that a cause of action arises for purposes of a limitation period when the material facts on which it is based have been discovered by the plaintiff by the exercise of reasonable diligence, and that rule should be followed and applied to the appeliant's cause of action in tort against the respondents under the Nova Scotia Statute of Limitations. ${ }^{17}$

Faced with the decisions of Kamloops and Rafuse, the Alberta Court of Appeal was called upon to consider the existence of the discoverability principle in the 1988 case of Fidelity Trust Company v. Weiler. ${ }^{18}$ Harradence J.A. delivered the judgment of the court and concluded that the discoverability principle laid down in Kamloops and Rafuse did not apply to contract actions in Alberta:

\begin{abstract}
Similarly, the traditional position is that the discoverability rule is not applicable to contractual relations.... Especially in light of the plaintifrs position in Central Trust with respect to the applicability of the discoverability rule in contractual actions, I am convinced that Le Dain J. would have provided a deeper analysis of the contractual situation had he wished to comment on it. I am unable to impugn the validity of Costigan on the basis of dicta extracted from a single passage from Central Trust which itself recognizes that the action under consideration was framed in tort. ${ }^{19}$
\end{abstract}

The reasoning of the unanimous court in Weiler demonstrated again that the discoverability principle will not be applied across the board to all types of civil actions in Alberta. There is a good argument that limitation periods relating to tort suits will be subject to the discoverability principle. If the action is framed so as to allege the defendant's concurrent liability in tort and contract, that also will apparently allow for the application of the discoverability principle. But suits involving only the express terms of a contract will most likely still be decided for limitations purposes in line with Costigan. ${ }^{20}$

In the result, the limitation period for a tort action will commence only after the plaintiff discovered, or reasonably ought to have discovered, the material facts which gave rise to his claim, while the limitation period for an action founded only on the express provisions of a contract will commence on the accrual of the cause of action

17 [1986] 2 S.C.R. 147 at 224 [hereinafter Rafuse].

18 [1988] 6 W.W.R. 427 (Alta. C.A.) thereinafter Weiler].

19Ibid. at 436. In Luscar Led. v. Pembina Resources Lid. (1992), 131 A.R. 79, the Court of Appeal received an application for leave to ask the court to reconsider its decision in Weiler. In dismissing the motion to seek such leave, Kerans J.A. delivered the oral judgment of the court and stated in part:

Moreover, no decision of the Supreme Court of Canada or a provincial Court of Appeal applies the discoverability rule in a case where the dispute is over the breach of an express term in a contract, as opposed to liability in tort arising from a contractual relationship. 
related to such contract regardless of whether the plaintiff could have discovered at that time the existence of facts material to the cause of action. It is therefore possible under present Alberta law that a plaintiff in a contractual dispute will be statute-barred from prosecuting an action in respect of the contract before the plaintiff becomes aware of the existence of such cause of action.

\section{Limitation Period for an ACtion to ReCover LaNd}

As earlier stated, under the present Act an action based on proceedings to recover land must be commenced within ten years after the right to do so first accrued to the claimant. ${ }^{21}$ Typically, such right will first accrue when a claimant is dispossessed of the land in question or an interest therein. A distinction in this area of the law pertinent for oil and gas matters turns on the difference between prosecuting an action to recover an interest in land, and prosecuting an action to expunge certain entries from the register maintained at the Alberta Land Titles Office in respect of the title to lands and for a corresponding declaration in respect of the claimant's interest in and to such title and lands. The distinction between the two types of actions was one of the matters dealt with in the 1954 Supreme Court of Canada decision of Turta v. Canadian Pacific Railway Company. ${ }^{22}$

The key facts in the Turta case are that the Canadian Pacific Railway Company ("C.P.R.") was the fee simple owner of a specific tract of land together with the coal and petroleum therein, and executed a transfer in respect of that land to and in favour of one Podgorny, excepting and reserving unto the C.P.R. "all coal and petroleum which may be found to exist within, upon or under the said land."23 Notwithstanding the wording of the transfer, a certificate of title for the land was issued in the name of Podgorny reserving unto the C.P.R. only "all coal on or under the land," thereby erroneously failing to reserve petroleum unto the C.P.R. Pursuant to a series of transfers, Anton Turta eventually acquired the land as a bona fide purchaser for value relying on the land titles register, and a certificate of title for the land was issued to Turta reserving only coal to the C.P.R.

In 1943, the error regarding the lack of reservation of petroleum unto the C.P.R. was discovered by the land titles registrar. The registrar attempted to rectify the error by restoring the full words "coal and petroleum" onto the C.P.R.'s certificate of title, and by amending Turta's certificate of title such that both coal and petroleum were excepted out of Turta's title. Subsequent to the attempted rectification, the C.P.R. purported to give a lease of petroleum rights in respect of the land. Turta eventually commenced an action seeking a declaration that he was the owner of the petroleum within the land in question. One of the arguments raised by the C.P.R. in defence of the action was that Turta was statute barred from prosecuting the action by the Limitation of Actions $A t^{24}$

Supra note 3, s. 18.

(1954), 12 W.W.R. 97 (S.C.C.) [hereinafter Turta].

Ibid. at 113.

R.S.A. 1942, c. 133. 
then in force. The pleadings submitted to the Supreme Court of Canada also put the possession of the said land and petroleum in issue.

The Supreme Court of Canada held by a majority of six to three that Turta should prevail and a certificate of title should issue showing Turta as the registered owner of the land and petroleum in question. Estey J. delivered the judgment of four of the six justices in the majority and decided the limitations argument raised by the C.P.R. was an action for the recovery of land since the pleadings of the parties raised the issue of the possession of the land during the time in question. Estey J. went on to hold that the limitation period for such an action was ten years, and that the action had been brought within that time period, with the result that Turta was not statute-barred from maintaining the action.

Rand J. wrote his own judgment in the majority and dealt with the limitations argument on a much broader basis than Estey $\mathrm{J}$, as illustrated by the following passage:

The remaining question is whether the action is barred by The Limitation of Actions Act. On the view which I have taken that the petroleum rights were acquired by Turta and the C.P.R. deprived of them, the possession, in the absence of physical workings and so far as such incorporeal rights can be the subject of possession, must be taken to be an incident of ownership. In the circumstances there has been no legal or physical disturbance of that possession; at the most, certain entries have been made on the certificate claiming rights which do not exist. The action is not, then, one to recover the land but to have those entries expunged and for a declaration of the plaintifrs interest. Since there has been no trespass and since the steps taken have, at the most, raised only a cloud upon the title, the question is whether an owner can be deprived of his land by the mere assertion on the register of unfounded claims. I know of no provision of law which, by the passage of time, raises any right based on that mode of protesting an interest; it would be a novel form of prescription which the law does not recognize. Its true interpretation is that of a continuing assertion against which proceedings of the nature here can be taken at any time, and no question of limitation arises. ${ }^{25}$

In the result, Rand $\mathrm{J}$. held that a limitation period was not applicable to the action before the Court, as the action sought only the declaration of Turta's true ownership rights and was not an action for the recovery of land within the context of the Limitation of Actions Act. The distinction made by Rand $\mathrm{J}$. has been applied in a number of cases decided after Turta. ${ }^{26}$

\section{THE LIMITATIONS ACT}

\section{A. Legislative Status of the New Act}

Bill 205, the Limitations $A c t,{ }^{27}$ was passed by the Alberta legislature on April 2, 1996, received royal assent on May 1, 1996, and will come into force upon 
proclamation which is anticipated to occur early in $1999 .{ }^{28}$ Upon proclamation, the new Act will repeal the present Act $^{29}$ and bring into effect a new limitations regime in Alberta. The key features of the new Act are summarized below. Generally, the new Act is concise and consists of only seventeen sections, and unlike the present Act, the new Act is drafted such that the fundamental limitation periods set forth apply to almost all manner of civil actions, regardless of the basis on which such actions are founded.

\section{B. SCOPE OF THE NEW ACT}

The new Act applies where a claimant seeks a remedial order $^{30}$ in a proceeding commenced after the new Act comes into force, whether the claim ${ }^{31}$ arose before or after the coming into force of the new Act. ${ }^{32}$ Subject to the foregoing, the new Act also applies to any claim for which a remedial order is sought in a proceeding before a provincially created court, or where the claim arose within Alberta and the remedial order for such claim is sought in a proceeding before a federally created court. ${ }^{33}$ The provincial Crown is bound by the new Act, ${ }^{34}$ and unlike the present Act, a claim based on a breach of trust is also subject to the same limitation period as other claims. The new Act also applies whenever a remedial order is sought in Alberta in respect of a claim, notwithstanding that, pursuant to applicable conflict of law rules, such claim is to be adjudicated in accordance with the substantive law of another jurisdiction. ${ }^{35}$

Notwithstanding the foregoing, the new Act does not apply to a claim where the claimant is seeking a remedial order based on adverse possession of real property owned by the Crown, or where a claimant seeks a remedial order, the granting of which is subject to a limitation provision in any other provincial enactment. ${ }^{36}$ In addition, the definition of remedial order under the new Act excludes from the scope of the new Act declarations of rights, enforcement of remedial orders, judicial review of administrative bodies and writs of habeas corpus. Finally, actions brought by an aboriginal people against the Crown based on a breach of fiduciary duty allegedly owed by the Crown to such people is excluded from the new Act and expressly made subject to the

The new Act came into force on 1 March 1999.

Supra note 24, s. 16.

Under s. 1(j) of the new Act, "remedial order" means a judgment or an order made by a court in a civil proceeding requiring a defendant to comply with a duty or to pay damages for the violation of a right, but excludes:

(1) a declaration of rights and duties, legal relations or personal status,

(2) the enforcement of a remedial order,

(3) judicial review of the decision, act or omission of a person, board, commission, tribunal or other body in the exercise of a power conferred by statute or regulation or

(4) a writ of habeas corpus.

Under s. 1(a) of the new Act, "claim" means a matter giving rise to a civil proceeding in which a claimant seeks a remedial order.

Supra note 27, s. 2(1).

Ibid., s. 2(1.2).

Ibid, s. 2(3).

Ibid., s. 12.

lbid., s. 2(2). 
provisions of the present Act, as if the present Act had not been repealed by the new Act.

\section{Limitation Periods and THe Discoverability PRINCIPLE UNDER THE NEW ACT}

All claims subject to the new Act will be governed by the two fundamental limitation periods. One period is known as the "discovery limitation period" and runs for two years, and the other period is known as the "ultimate limitation period" and runs for ten years. A defendant to a claim will be entitled to a limitations defence under the new Act in respect of such claim upon the expiration of either one of the two periods. However, as with the present Act, a limitations defence under the new Act is not automatically considered by the courts and must be expressly pleaded by a defendant.

Paragraph 3(1)(a) of the new Act incorporates a discoverability principle. ${ }^{37}$ The discoverability principle incorporates a constructive knowledge test which charges the claimant with knowledge of the facts which, in the circumstances, he ought to have known based on a objective standard of a reasonable man. ${ }^{38}$ The date determined by the discoverability criteria set forth in paragraph 3(1)(a) will be the date on which the two year discovery limitation period begins to run. Once a claim has been, or in the circumstances ought to have been, known by a claimant as determined in accordance with paragraph $3(1)(a)$, the claimant will then have two years in which to commence his claim, after which the defendant to such claim will be entitled to a limitations defence.

The new Act also contains a "successor" provision which is applicable to the discovery limitation period and which will have wide applicability in the oil and gas industry. Subsection 3(2) of the new Act provides that the two year discovery limitation period begins against a successor owner of a claim when either a predecessor owner or the successor owner of the claim first acquired or ought to have acquired the knowledge prescribed by the discoverability principle promulgated in the new Act.

The ultimate limitation period of the new Act is ten years and commences on the date on which a particular claim accrued to the claimant. Subsection 3(3) sets forth criteria to be used in determining when, in certain enumerated circumstances, a cause

Paragraph 3(1)(a) states in part:

if a claimant does not seek a remedial order within 2 years after the date on which the claimant first knew, or in the circumstances ought to have known: (i) that the injury for which the claimant seeks a remedial order had occurred, (ii) that the injury was attributable to conduct of the defendant, and (iii) that the injury, assuming liability on the part of defendant, warrants bringing a proceeding ... the defendant, upon pleading this Act as a defence, is entitled to immunity from liability in respect of the claim.

Under the new Act, "injury" means personal injury, property damage, economic loss, nonperformance of an obligation or in the absence of any of the foregoing, the breach of a duty. 
of action accrues to a claimant for purposes of determining the commencement date of the ultimate limitation period applicable to such claim. ${ }^{39}$

Generally, all claimants have ten years from the date on which a cause of action arose to prosecute the claim, regardless of the date on which the claimant discovered, or reasonably ought to have discovered, the existence of such claim. Subject to certain exceptions contained in the new Act, a defendant to a claim will be entitled to a limitations defence under the new Act after the expiration of the ultimate limitation period, regardless of whether the claimant knew of the existence of such claim or not.

In respect of the two fundamental limitation periods contained in the new Act, subsection 3(5) states that the claimant has the burden of proving that a remedial order was sought within the two year discovery limitation period, and the defendant has the burden of proving that a remedial order was not sought within the ten year ultimate limitation period.

\section{Transition Period for the New ACt}

The transition provision contained in subsection 2(1.1) of the new Act provides that if before the new Act comes into force: (1) a claimant knew, or in the circumstances ought to have known, of a claim; and (2) the claimant has not sought a remedial order in respect of such claim before the earlier of the time provided by the present Act and two years after the coming into force of the new Act - then the defendant to such claim, on pleading the new Act as a defence, will be entitled to immunity from liability in respect of that claim.

At first glance the transition provision of the new Act may seem inconsistent with the overall scheme. However, the transition provision is entirely consistent with the discoverability principle set forth in the new Act. Specifically, the transition provision is only triggered when a claimant knew, or ought to have known, of a claim before the proclamation date of the new Act. In effect, the transition period deems the proclamation date of the new Act as the date on which the two year discovery limitation period commences to run, but does so in respect of only those claims which a claimant knew, or ought to have known, existed before the proclamation date of the new Act.

\section{E. Exceptions to the Limitation Periods UNDER the NeW ACt}

The new Act contains certain exceptions to the two fundamental limitation periods. Section 4 of the new Act states that the operation of the ten year ultimate limitation period is suspended during any period of time that a defendant to a claim fraudulently conceals the fact that the injury for which a remedial order is sought has occurred. That

The problematic area of continuing breach is clarified by paragraph 3(3)(a) of the new Act. That paragraph states that "a claim or any number of claims based on any number of breaches of duty, resulting from a continuing course of conduct or a series of related acts or omissions arises when the conduct terminates or the last act or omission occurs." 
section also requires that the claimant has the burden of proving that such limitation period was suspended for such reasons.

Under section 7 of the new Act, a claimant and defendant can by agreement expressly provide for the extension of a limitation period contained in the new Act.

Subsection $8(2)$ also contains a provision which can have the effect of extending a limitation period contained in the new Act. That subsection states that if a person liable in respect of a claim acknowledges the claim, or makes a part payment in respect of the claim before the expiration of the limitation period applicable to the claim, the commencement of the limitation period applicable to the claim begins again at the time of the acknowledgment or part payment. The new Act does not contain any provision which mentions the possibility of shortening a limitation period.

\section{OIl and Gas Transactions and limitation Considerations}

\section{A. Limittation Considerations Under the Present ACt and the New ACt}

Over the years, the Alberta courts have decided a number of oil and gas related disputes that involved a limitation issue. Due to the variety of limitation periods under the present Act, a plaintiff prosecuting such an action would occasionally be faced with the situation where his action would be statute-barred if it were based on a particular cause of action, such as tort, but would not be statute-barred if it were based on a different cause of action, such as contract or the breach of a trust relationship. Obviously, the plaintiff in that circumstance would seek to frame the action such that it would not be statute-barred.

Cases decided under the present Act are replete with examples where the court seeks to categorize the particular action so as to ascertain the applicable limitation period. Such categorization is a prerequisite for the determination by the court of whether the action was brought within the applicable limitation period. The latter consideration, of course, also requires that the court determine the commencement date of the applicable limitation period, which typically involves deliberation as to whether the discoverability principle applies to the action in question. The new Act renders much of this analysis unnecessary.

As previously discussed, the new Act sets forth two fundamental limitation periods which, subject to certain specific exceptions, are applicable to every claim commenced under the new Act. The scheme of having all claims subject to the same limitation periods eliminates the need to categorize each individual claim and ascertain the applicable limitation period. The distinction between a breach of contract and a breach of trust, and the determination of whether or not a royalty is an interest in land will be much less important in actions brought under the new Act insofar as limitation issues are concerned. 
In light of the foregoing, it is apparent that the proclamation of the new Act will radically change certain time-honoured considerations in the practice of limitations law in Alberta.

\section{B. Oll and Gas Cases Decided Under the Present act}

Notwithstanding that much of the analysis required in respect of limitation periods under the present Act will be rendered obsolete upon proclamation of the new Act, the oil and gas cases decided under the present Act are, of course, still representative of the types of disputes that arise in oil and gas related transactions. Each of the oil and gas cases that follow were decided under the present Act and involved deliberation by the court in respect of the limitation period applicable to the action in question.

Two Alberta cases decided in the 1990s illustrate the extensive analysis required under the present Act to ascertain the limitation period applicable to a specific action. In the 1991 Alberta Court of Queen's Bench case of United Canso Oil \& Gas Ltd. v. Wahoe Northern Inc., ${ }^{40}$ Hutchinson J. embarked on an exhaustive analysis in ascertaining the limitation period applicable to an action brought in respect of the failure to maintain proper accounts during the period from 1969 to 1987, which had the effect of depriving the plaintiff of significant revenue during that period. Hutchinson $\mathrm{J}$. held that the action was founded in contract and that the limitation period applicable to the action was six years. Further, Hutchinson J. applied Costigan ${ }^{41}$ and held that the limitation period commenced when the first breach occurred, namely, in 1969. In the result, the plaintiff was statute-barred from prosecuting an action in respect of any breach of contract that occurred more than six years before 6 February 1987, the date on which the plaintiff's statement of claim was issued.

Another case decided by the Alberta Court of Queen's Bench in 1991 involving an extensive analysis of applicable limitation periods was Luscar Ltd. v. Pembina Resources $L t d{ }^{42}$ The cause of action was framed concurrently in contract and tort. Egbert J. analyzed the facts of the case and the law applicable to each type of action and concluded that the limitation period for the contract action was six years, commencing on the date of the breach of the contract in 1971. Accordingly, Egbert J. held that an action commenced in 1986 in respect of the breach of contract that occurred in 1971 was statute-barred under the present Act.

The court then analyzed the tort-based element of the action and found that the defendant was unjustly enriched as a consequence of a breach of fiduciary duty. Egbert J.'s analysis led him to conclude that the limitation period for an action brought in respect of this unjust enrichment was six years, commencing in 1983 when the plaintiff discovered the existence of the cause of action based on the unjust enrichment. In the result, Egbert J. held that the plaintiff's action based on unjust enrichment was not statute-barred as it was commenced well within the six year limitation period.

(1991), 121 A.R. I (Q.B.) [hereinafter United Canso].

Supra note 16.

(1991), 122 A.R. 83 (Q.B.) [hereinafter Luscar]. 
The defendant in Luscar appealed the decision to the Alberta Court of Appeal, and in 1994 Conrad J.A. delivered the judgment of two of the three judges of the unanimous Court allowing the appeal. ${ }^{43}$ In her judgment, Conrad J.A. affirmed the finding of the trial court in respect of the contract-based action. However, the court held that the facts did not support a claim based on unjust enrichment, and therefore did not address the limitation period for such a claim.

A further issue in limitation jurisprudence for oil and gas transactions is whether the action at bar is in respect of an interest in land, with the consequent result that a ten year limitation period applies. In the 1963 Saskatchewan Court of Queen's Bench case of Dorsch v. Freeholders Oil Co. ${ }^{44}$ the defendant argued that the action was statutebarred on the basis that it was founded in contract and brought outside of the applicable six year limitation period. Davis J. reviewed the oil and gas lease in question and held that it granted a profit à prendre, and therefore created an interest in land. Accordingly, the court held that the applicable limitation period for the action was ten years and since the action was commenced within that time period, it was not statute-barred. ${ }^{45}$

In the 1981 Alberta Court of Queen's Bench decision of Western Oil Consultants v. Great Northern Oils Ltd. ${ }^{46}$ the court was required to determine whether a farmout and overriding royalty agreement created an interest in land. Under the agreement, the defendant was to notify the plaintiff before surrendering any of the lands covered by the agreement, so as to afford the plaintiff the opportunity to acquire and prevent the surrender of such lands. Unfortunately, the defendant did surrender some of the lands covered by the agreement and allegedly failed to notify the plaintiff of such surrender.

In considering the limitation defence raised by the defendant, Patterson J. held that the agreement did not create an interest in land, and that any action brought in respect of a breach of the agreement was subject to only a six year limitation period and not a ten year limitation period. Based on the applicable limitation period, the court held that the action commenced in respect of three parcels of land covered by the agreement and surrendered by the defendant contrary to the agreement was statute-barred as the action was commenced more than six years after the defendant had surrendered the three parcels of land.

In the 1992 case of Prism Petroleum Ltd. v. Omega Hydrocarbons Ltd., ${ }^{47}$ Egbert J. of the Alberta Court of Queen's Bench was called upon to adjudicate a dispute involving the ownership of solution gas produced from a particular reservoir. In so doing, Egbert J. considered whether the action was barred under the present Act. In making such determination, the court held that the solution gas in question constituted an interest in land and that the limitation period for such an action was ten years. The

Luscar Lid. v. Pembina Resources Lid. (1994), 162 A.R. 35 (C.A.).

(1963), 40 D.L.R. (2d) 307 (Sask. Q.B.).

The findings of the trial judge in respect of the applicable limitation period were not disturbed by the Saskatchewan Court of Appeal (1964), 48 W.W.R. 257, nor by the Supreme Court of Canada, [1965] S.C.R. 670.

(1981), 15 Alta. L.R. (2d) 165 (Q.B.).

(1992), 4 Alta. L.R. (3d) 332 (Q.B.). 
court further held that such limitation period commenced when the solution gas was first produced and that the action had been brought within ten years of that time. On appeal, the Alberta Court of Appeal dealt with other issues in the case and did not disturb these findings. ${ }^{48}$

In the recent, and as yet, unreported judgment of Bearspaw, Chiniki and Wesley Bands v. PanCanadian Petroleum Ltd., ${ }^{49}$ McIntyre J. of the Alberta Court of Queen's Bench held that the particular lessor's royalty at issue was an interest in land and that the limitation period applicable to actions arising in respect of the royalty was ten years. McIntyre $\mathbf{J}$. also held that the action in question was commenced within that ten year time period and was therefore not statute-barred. ${ }^{30}$

Another area that involves the application of limitation periods to oil and gas related matters arises in respect of the registration of mines and minerals on the various certificates of title maintained under the Land Titles Act. ${ }^{51}$ As earlier discussed, the Supreme Court of Canada decision in Turta ${ }^{52}$ demonstrated the distinction between an action for the recovery of land, to which a limitation period of ten years is applicable under the present Act, and an action for a declaration in respect of the interest of the registered titleholder of the lands in question and a corresponding order to expunge certain entries from the title of such lands. In Turta, the Supreme Court of Canada held that no limitation period was applicable to the latter type of action, as such action was not a proceeding to recover land. That principle has been applied in a number of subsequent decisions. ${ }^{53}$

A case which involved an action arising from a plaintiff's deprivation of land is the 1989 Alberta Court of Appeal decision of McWhorter v. Alberta (Registrar, North Alberta Land Registration District). ${ }^{54}$ In that case, title to certain lands was taken by a local municipal district in 1943 from the plaintiff's predecessor in title, pursuant to tax recovery proceedings. Notwithstanding that the municipal district should only have received title to the surface lands and not to the minerals within the lands, the land titles registrar issued a certificate of title to the municipal district for both the surface lands and the minerals therein, and cancelled the entire interest of the plaintiff's predecessor in and to the lands and minerals. In 1944, the municipal district sold the entire interest to Krautt, a bona fide purchaser for value without notice of the interest of the plaintiff's predecessor. In 1946, the registrar discovered the earlier error and

Prism Petroleum Lid. v. Omega Hydrocarbons Lid. (1994), 18 Alta. L.R. (3d) 225 (C.A.).

[1998] A.J. No. 381 (Q.B.) [hereinafter Bearspaw].

The defendant in the Bearspaw case had argued that the royalty interest in question was not an interest in land, and that a six year limitation period was applicable to any action commenced in respect of the royalty. The plaintiff's action would have been statute-barred had the court acceded to the defendant's arguments.

R.S.A. 1980, c. L-S.

Supra note 22.

The following cases applied the principle enunciated in Turta: Kaup v. Imperial Oil Lid. (1962), 37 W.W.R. 193 (S.C.C.); Clarke v. Burton (1958), 27 W.W.R. 352 (Alta. S.C.A.D.); and Morris v. Public Trustee (Wilkins Estate) (1958), 26 W.W.R. 471 (Alta. S.C.T.D.).

67 Alta. L.R. (2d) 71 (C.A.), affg, [1988] 3 W.W.R. 132 (Alta. Q.B.). 
deleted the minerals from Krautt's title, restoring them to the title of the plaintiff's predecessor. In 1981, Krautt successfully sued for a declaration that he was the owner of the minerals in question. Consequently, the plaintiff's interest in and to the minerals was expunged from the register. In 1988, the plaintiff commenced an action against the registrar for damages resulting from the deprivation of the minerals in question from the plaintiff's predecessor in title.

Upon hearing the case, the Court of Appeal held that a ten year limitation period applied to the action as it was based on proceedings relating to land. Notwithstanding that the plaintiff asserted that the ten year limitation period commenced in 1981 when the plaintiff was deprived of the minerals in question, the Court of Appeal held that the limitation period commenced in 1943 when the plaintiff's predecessor in title was first deprived of the minerals. In the result, the court held that the action was statute-barred by the ten year limitation period applicable under the present Act. ${ }^{55}$

\section{The Effect of the New act on OIL and Gas Transactions}

One major impact of the new Act on disputes arising out of oil and gas transactions is that it will no longer be necessary, at least in cases where there is a limitation issue, to characterize the nature of the relationship between the parties. It will not matter if the plaintiff and defendant were mere contracting parties, beneficiary and trustee, or relative strangers whose actions might foreseeably injure each other - the limitation periods are the same in all such cases.

This result has some exceptions since, under the new Act, no limitation period is applicable to a claim which seeks as its remedy a declaration of rights, as that remedy is expressly excluded from the new Act's definition of "remedial order." The same circumstance exists under the present Act, as noted by the Supreme Court of Canada in the Turta $^{56}$ decision where the court held that no limitation period applies to an action which seeks a declaration of rights in respect of a title for a certain piece of land. The distinction between an attempt to recover land and to obtain a declaration of one's rights will still be important.

Another characterization that will be less important relates to the nature of the interest in dispute. It will not matter, at least for limitation purposes, if a royalty or a net profits interest is an interest in land or not.

Since the predominate type of relationship that exists among companies in the Alberta oil and gas industry is contractual, and since the new Act, as compared to the present Act, reduces the limitation period for a claim based on a breach of contract

Another area of limitations jurisprudence involving actions based on the recovery of land relates to cases where the plaintiff seeks to acquire title to certain lands based on prescription and adverse possession coupled with the invocation of the ten year limitation period applicable to such actions under the present Act. The following two cases are illustrative of an action of this type: Edwards v. Duborg, [1982] 6 W.W.R. 128 (Alta. Q.B.); and Duncan v. Joslin (1965), 51 W.W.R. 346 (Alta. S.C.A.D.), aff'g (1964), 46 D.L.R. (2d) 175 (Alta. S.C.T.D.). 
from six to two years, the new Act may have a noticeable effect on the amount of litigation in the industry simply because parties will have less time to discuss and resolve matters before facing a limitation deadline. This was contemplated by the Alberta Law Reform Institute when it suggested the model limitations act on which the new Act is based. In response, the institute included an express provision permitting extension of the statutory limitation periods into its model act.

Section 7 of the new Act simply states that "if an agreement expressly provides for the extension of a limitation period provided by this Act, the limitation period is altered in accordance with the agreement." Accordingly, the limitation period applicable to a contractual breach can be easily extended by a written agreement between the parties to the contract. ${ }^{57}$ Subsection 8(2) of the new Act states that "if a person liable in respect of a claim acknowledges the claim, or makes a part payment in respect of the claim, before the expiration of the limitation period applicable to the claim, the operation of the limitation period begins again at the time of the acknowledgment or part payment."

The mechanisms provided in sections 7 and 8 of the new Act afford an oil and gas company the opportunity to extend the limitation period applicable to a claim of the company, thereby avoiding the expense associated with commencing and prosecuting the claim, and providing the defaulting party with the opportunity to remedy its breach or default. The tendency in the oil and gas industry has always been to limit risk by contractually reducing limitation periods. It therefore seems unlikely that the shorter two year discovery limitation period under the new Act which will apply to contractual breaches will result in oil and gas companies seeking to contractually lengthen that period.

The payment of royalties is an area that has always caused some degree of concern in the context of limitation law. Often the payee of a royalty will receive only a cheque and perhaps some production or accounting statements. Under the present Act, if the payments were incorrectly made over a long period of time the royalty payee may be statute-barred from recovering payments which should have properly been made to him, as was shown by the outcome of the United Canso ${ }^{\text {s8 }}$ case. Under the new Act, a royalty payee has two years (subject always to the earlier expiration of the ten year ultimate limitation period) from the date on which the payee knew or ought to have known of the claim, in which to seek a remedial order in respect of the claim. Since the commencement date of the limitation period is tied to the date on which the payee knew or ought to have known the claim, it is foreseeable that the courts will likely place a great deal of emphasis on the information delivered to the payee in respect of any royalty payments that are the subject of a claim.

$37 \quad$ Section 9 of the new Act sets forth certain conditions which must be met in order for an agreement to be effective under section 7. One of the conditions is that the agreement must be in writing and signed by the person adversely affected. 
The increase in clarity as to when a limitation period ends may well be offset by the increase in difficulty in determining when a limitation period begins. In the situation of an incorrect payment of a royalty or net profits interest, or the situation where a lease might be erroneously permitted to expire, and in other circumstances where the aggrieved party is not actively involved in day-to-day operations but relies on information provided by a more active party, an analysis may be required to determine when the plaintiff knew or reasonably ought to have known of the facts giving rise to his claim. This is as complex as any analysis required to characterize a relationship or interest under the present Act. It seems likely that the courts will apply different standards to a plaintiff who is a lessor royalty owner involved in the agricultural industry as compared to a major oil and gas company that has an overriding royalty.

The successor provisions contained in subsection 3(2) of the new Act state that the two year discovery limitation period begins against a successor owner of a claim when that owner or a predecessor owner first acquired, or ought to have acquired, the knowledge prescribed by the discoverability principle incorporated in the new Act. Accordingly, an oil and gas company acquiring any right or interest from another party should satisfy themselves as to whether any claim exists in favour of the disposing party and when that claim arose to ensure a defendant will not be immune from liability.

\section{SUMMARY}

The case law examined in this article provides ample evidence that the limitations scheme currently in force in Alberta is convoluted and complex. It is clear that under the present Act different causes of action will have limitation periods that have different lengths and commencement dates, even in the circumstance where more than one type of cause of action arose from a single individual event. One of the goals of the new Act was to simplify and streamline the analysis required to ascertain the length and commencement date of a limitation period applicable to a particular action. It may be, however, that one of the results of the new Act will be to shift the battleground from the characterization of interests and relationships, to one of characterizing the experience, size and sophistication of plaintiffs and defendants. 